\title{
Nurses' Care Provided to Burned Children at Assiut Hospitals
}

\author{
Mary Mazhar Youssef, Youssef Saleh Hassan, Asmaa Abd El-Aziz \& Hend Sayed Mohammed. \\ 1. Nursing specialist, Technical Institute of Nursing, Assiut University, Egypt. \\ 2. Professor of Plastic Surgery, Faculty of Medicine, Assuit University, Egypt. \\ 3. Assistant Professor of Pediatric Nursing, Faculty of Nursing, Assuit University, Egypt. \\ 4. Lecturer of Pediatric nursing, Faculty of Nursing, Assuit University, Egypt.
}

\begin{abstract}
Background: Burns are one of the most common forms of trauma in children. Providing adequate care for burnt children properly is the most important contribution to the successful management. It aimed to determine nurses' care provided to burn children at assiut hospitals. Research design: A descriptive research design was utilized in the current study. Sample A convenience sampling (50) nurses working at burn unit in Assiut University Hospital, Assiut General Hospital and El-Emane Elarbaeen Hospital. Two tools were used to collect the necessary data, interview questionnaire sheet and observational checklists. Results It was found that (96.0\%) had incompetent level of knowledge regarding burn and its management while (74\%) of them had competent level of practice regarding nurses' care of pediatric burn. There was statistically significant positive co-relation between total mean score of nurses' knowledge and practice ( $\mathrm{P}=0.036)$. Conclusion: the majority of nurses had incompetent level of knowledge and more than two thirds of them had competent practice care. Recommendations: Periodical educational training programs for nurses working at burn unit are mandatory for updating knowledge and to maintain effective practice.
\end{abstract}

\section{Key words: Nurses' Care \& Burned Children.}

\section{Introduction}

A burn is defined as an injury to the skin or other organic tissue principally caused by heat or due to radiation, radioactivity, electricity, friction or contact with chemicals. In Egypt, 17\% of children with burns have an impermanent inability to care for themselves and 18\% have a changeless handicap (World Health Organization, 2016).

Burn injuries cause a significant insult on the body and a thorough $\mathrm{ABCD}$ assessment, followed by full head to toe and focused assessment are vital to ensure clinical deterioration are identified early and appropriate management initiated (Edwards\& Coyne,2019). Assessment of the pediatric patient with burn injury should occur on admission, when the patient's condition changes regularly throughout care (Gonzalez \& Shanti, 2015).

The Institute of Medicine suggests that nurses play a pivotal role in preventing patient complications, identifying incidences of risk, and activating appropriate responses and processes which are all functions essential for patient safety (Henneman, et al., 2012).

The burn nurse is a valuable member of the burn care team with unique insights and specialized skills that are paramount to the successful outcome of the burn patient. Burn nurses care for their patients throughout the continuum of critical illness to health and recovery. A wide range of skills is needed to provide care throughout this continuum. From emergency care to care for the burn wound to rehabilitation and recovery, the nurse can have a tremendous impact on patient survival and patient outcomes. Clinical outcomes can be assessed through research activities and quality improvement programs, which can lead to improvements in clinical care (Benjamin \& Jaco, 2018).

Nursing care of burn is one of the most challenging specialties in nursing. It calls for sharp clinical skills including triage, pain management, fluid balance, and critical care, the stabilization of acutely burned patients, trauma recovery, and rehabilitation. The nurse working in the burn unit, must be knowledgeable in using several different types of equipment and techniques to observe, treat, monitor and ventilate patients when necessary (Price, 2016). Individual patient outcomes may be best measured from a patient's successful recovery and reintegration into society. Nursing in burn care includes a broad spectrum of patient-related interventions such as hemodynamic alterations, wound care, nutritional and metabolic support, and assessment and management of pain and anxiety. Later in the process, the nurse is involved in rehabilitation interventions preparing the patient for discharge. The responsibilities also include family education, which needs to be adjusted to the specific family structure (Ahuja, et al., 2016). Nurses are the frontline of care and possess many roles within the care of pediatric burn patients. 
Nursing roles in pediatric burn care can be organized into three noteworthy ranges of care including acute, rehabilitative and psychological. It is the roles that nurses carry out that make a difference in the longterm quality of life in the pediatric burn patient (Ahmed, 2016).

\section{Significance of the study}

Burns are a common cause of accidental deaths and also consider an important public health problem in a developing country like Egypt. Children burns result in 2,500 deaths and over 100,000 emergency room visits every year. Burns of children is considered the fourth leading cause of death under the age of 15 , and the majorities are under the age of five years and the number one cause of accidental death occurring in the home. Burn injuries are also a major source of pediatric disability and are associated with significant national health care resource utilization. Burns are the fourth most common type of trauma worldwide. World Health Organization (WHO) highlights the need for improvements burn care. The caring of children with burn include burning injury dressing, prevent infections and appropriate pain management, so good training of nurses are very important to prevent complication and study challenged facing them trying to overcome it for effective care According to (Center for Research Injury \& Policy, CRIP, 2010).So, the current study will assess the nurses' competency to detect clinical deterioration in pediatric burn patient.

\section{Aim of the study}

The aim of this study is to determine nurses' care provided to burn children at Assiut hospitals.

\section{Research questions}

1- Do nurses have good level of knowledge regarding nursing care for pediatric burn patient?

2- Do nurses have good level of practice regarding nursing care for pediatric burn patient?

3- Are there relations between nurses' knowledge and practice given to burned child?

\section{Subjects \& Method \\ Research design}

A descriptive design was used for present study.

\section{Settings of the study}

This study was conducted in burn unit at Assiut

University Hospital, Assiut General Hospital and El-

Emane - Elarbaeen Hospital.

Subject

Convenience sampling was used to include the nurses from the previous mentioned settings; the total number was 50 nurses (all nurses in the unit).
Tools of data collection

Two tools were used for data collection after reviewing of related literature.

Tool (1): A structured questionnaire interviewing sheet:

It was developed by the researcher after reviewing of related literature and it divided into two parts:

Part (1) :Personal characteristics of the studied nurses such as

Name, age, level of education, years of experience in pediatric burn unit and attending training courses about burn care.

Part (2): Nurses knowledge about burn of children:

Nurses knowledge about burn of children it was adopted from (Ahmed \& Mohammed 2016) knowledge about burn include 18 items regarding (Meaning of burn , Type of burn , Degree of burn , Methods of burn depth assessment, Medication for pediatric burn patient, Side effects , Complications, Specific needs of pediatric burn patient, Developmental and psychological issues, Formal counseling, Mobilization, Scare management, Pain assessment and management, Grafting , Nutrition, Fluid and electrolyte balance, Infection control measures and Nursing care for burn patient)

Scoring system: Scoring system for knowledge of the studied nurses was calculated as the following: the total number of questions was (18) questions and the total score of (36) were given for knowledge. Where (2) scores was given for completely correct answer, (1) for incompletely correct answer, and (0) for do not know. The total level of knowledge divided into

Competent: $75 \%$ and more (equal 27 grade and more).

Incompetent: less than $75 \%$ (equal less than 27 grade).

Tool (2): Nurses' competence related to care of pediatric burn:

It included a structure observational checklist for care of pediatric burn. It was adopted from (American burn association 2015) to assess nurses' practice in care pediatric burn patients. It include ( 46 ) steps as prepare sterile dressing materials, clean burns daily and remove dead tissues, and evaluate burn area for color and healing....etc.

Scoring system: the total scores of nurses' practice were (92) for all the nursing procedures carried out for care of burned child (46 items for care provided to burned child). The nurses' was practice classified into either completely done (2), incompletely done (1), and not done $(0)$. The total level of practice divided into: competent: ( $75 \%$ and more).

Incompetent: (less than $75 \%$ ). 
Data collection: A written permission was obtained from the dean of the faculty of nursing to the burn unit at Assiut University Hospital, Assiut General Hospital and El-Emane_Elarbaeen Hospital. The aim and methodology of the study were explained to administrators and as well as potential participants.

Pilot study it was conducted on $10 \%$ of nurses' ( 5 nurses ) to evaluate the clarity, applicability of the sheet and understanding of the tools, It helped in making necessary changes in the tools to detect data collection problems or difficulties. It also helped to determine the time needed to fill the form. The time needed to fill out the sheet was 25-30 minutes. The data obtained from the pilot study were analyzed; no change was done in the questions, so they were included in the study. The nurses' who was tested in the pilot study was included in the main study sample. Following the pilot study, the questionnaire was finalized and made ready for use.

Validity: The validity of tool was tested by measuring its Content Validity Index (CVI) by jury (5 nursing experts) after translation from English to Arabic version to test validity of it. The content validity for tool (1) was 0.799 and for tool (2) was 0.815 .

Reliability: test was done using alpha Crombach's test was done to be accepted reliability it was ( $\mathrm{r}=$ 0.79).

\section{Fieldwork}

This study was carried out through a period of 7 months from (the beginning of December 2018 to the end of June 2019). It was done every other day at burn unit. Interviewing of studied nurses was conducted according to their available time in the morning shift to collect data; two or three nurses were interviewed per day. The time needed for each interview questioner sheet ranged from 25-30 minutes according to the response of the participant nurses. Indirect observation for nursing practice regarding care of burn children was done individually for each nurse. The time needed for observing every each nurse ranged from 1-2 hours. Only one nurse observed per day.

\section{Ethical considerations}

- Research proposal was approved from ethical committee in the faculty of nursing, Assiut University.

- There is no risk for study subjects during application of the research.

- The study was followed common ethical principles in clinical research.

- Written consent was obtained from nurses' that participate in the study after explaining the nature and purpose of the study.
- Confidentiality and anonymity was assured.

- Study subjects have the right to refuse to participate or withdraw from the study without any rational at any time.

- Study subjects privacy was considered during collection of data.

Statistical Analysis of data

Data entry was done using a compatible personal computer. The statistical analysis was done using (SPSS) version 21 statistical software package and Excel for figures. The content of each tool was analyzed, categorized and then coded. Data were presented using descriptive statistics in the form of frequencies and percentage for qualitative variables. Comparison between variables was done using chisquare test. Probability ( $\mathrm{p}$-value) less than 0.05 was considered significant. 


\section{Results}

Table (1): Characteristics of studied nurses $(n=50)$.

\begin{tabular}{|c|c|c|}
\hline Characteristics & No $=50$ & $\%$ \\
\hline \multicolumn{3}{|l|}{ Age group /years } \\
\hline From 20- years & 24 & 48.0 \\
\hline From 25- years & 6 & 12.0 \\
\hline More than 30 years & 20 & 40.0 \\
\hline Mean \pm SD & \multicolumn{2}{|c|}{$30.63 \pm 11.22$} \\
\hline \multicolumn{3}{|l|}{ Marital Status } \\
\hline Single & 22 & 34.0 \\
\hline Married & 27 & 54.0 \\
\hline Widowed & 1 & 2.0 \\
\hline \multicolumn{3}{|l|}{ Educational Level } \\
\hline Nursing Diploma & 17 & 34.0 \\
\hline Nursing Diploma + specialty & 3 & 6.0 \\
\hline Nursing Technician Institute & 15 & 30.0 \\
\hline Bachelor of Nursing & 4 & 8.0 \\
\hline Healthy Technical Institute & 11 & 22.0 \\
\hline \multicolumn{3}{|l|}{ Years of experience } \\
\hline$>1$ year & 11 & 22.0 \\
\hline From 1- years & 14 & 28.0 \\
\hline From 5- years & 4 & 8.0 \\
\hline More than 10 years & 21 & 42.0 \\
\hline \multicolumn{3}{|l|}{ Training Courses } \\
\hline Yes & 46 & 92.0 \\
\hline No & 4 & 8.0 \\
\hline \multicolumn{3}{|c|}{ If the course is related to burns, what is the subject? } \\
\hline Nursing care for burns patients & 30 & 60.0 \\
\hline Methods of infection control for burns patients & 17 & 32.0 \\
\hline Proper nutrition for burns patients & 3 & 8.0 \\
\hline
\end{tabular}

Table (2): Knowledge of studied nurses regarding burn.

\begin{tabular}{|c|c|c|c|c|c|c|}
\hline \multirow{2}{*}{ Nurses Knowledge } & \multicolumn{2}{|c|}{ Not known } & \multicolumn{2}{|c|}{ Incompletely correct } & \multicolumn{2}{|c|}{ completely correct } \\
\hline & No & $\%$ & No & $\%$ & No & $\%$ \\
\hline Meaning of burns & 1 & 2.0 & 40 & 80.0 & 9 & 18.0 \\
\hline Type of burns & 2 & 4.0 & 38 & 76.0 & 10 & 20.0 \\
\hline What are the degrees of burns? & 8 & 16.0 & 39 & 78.0 & 3 & 6.0 \\
\hline Methods of burns depth assessment & 7 & 14.0 & 21 & 42.0 & 22 & 44.0 \\
\hline Medications for pediatric burn patient & 17 & 34.0 & 33 & 66.0 & 0 & 0.0 \\
\hline Side effects & 13 & 26.0 & 25 & 50.0 & 12 & 24.0 \\
\hline Complications & 1 & 2.0 & 49 & 98.0 & 0 & 0.0 \\
\hline Specific needs of pediatric burns patients & 9 & 18.0 & 38 & 76.0 & 3 & 6.0 \\
\hline Developmental and psychological issues & 7 & 14.0 & 23 & 46.0 & 20 & 40.0 \\
\hline Formula counseling & 0 & 0.0 & 26 & 52.0 & 24 & 48.0 \\
\hline Mobilization & 9 & 18.0 & 15 & 30.0 & 26 & 52.0 \\
\hline Scare management & 5 & 10.0 & 45 & 90.0 & 0 & 0.0 \\
\hline Pain assessment and management & 2 & 4.0 & 37 & 74.0 & 11 & 22.0 \\
\hline Grafting & 6 & 12.0 & 22 & 44.0 & 22 & 44.0 \\
\hline Nutrition & 1 & 2.0 & 24 & 48.0 & 25 & 50.0 \\
\hline Fluid and electrolyte balance & 0 & 0.0 & 44 & 88.0 & 6 & 12.0 \\
\hline Infection control measures & 0 & 0.0 & 15 & 30.0 & 35 & 70.0 \\
\hline Nursing care & 0 & 0.0 & 0 & 0.0 & 50 & 100.0 \\
\hline
\end{tabular}


Table (3): practice of studied nurses regarding burn.

\begin{tabular}{|c|c|c|c|c|c|c|}
\hline \multirow[t]{2}{*}{ Nurses' practice } & \multicolumn{2}{|c|}{ Not done } & \multicolumn{2}{|c|}{$\begin{array}{c}\text { Done } \\
\text { incomplete } \\
\text { correct }\end{array}$} & \multicolumn{2}{|c|}{$\begin{array}{c}\text { Done } \\
\text { complete } \\
\text { correct }\end{array}$} \\
\hline & No & $\%$ & No & $\%$ & No & $\%$ \\
\hline 1. Write done full name of child & 0 & 0.0 & 2 & 4.0 & 48 & 96.0 \\
\hline 2. Write done causes of injury & 14 & 28.0 & 24 & 48.0 & 12 & 24.0 \\
\hline 3.Assess percentage and the degree of burns & 15 & 30.0 & 32 & 64.0 & 3 & 6.0 \\
\hline 4.Put done date of admission in the hospital & 0 & 0.0 & 2 & 4.0 & 48 & 96.0 \\
\hline 5.Write done child's age & 1 & 2.0 & 0 & 0.0 & 49 & 98.0 \\
\hline 6.Write done child's address & 0 & 0.0 & 13 & 26.0 & 37 & 74.0 \\
\hline 7.Ask about child's past and present medical history & 40 & 80.0 & 9 & 18.0 & 1 & 2.0 \\
\hline 8.Wright done name of physician & 0 & 0.0 & 0 & 0.0 & 50 & 100.0 \\
\hline 9.Preparation of the child's bed & 0 & 0.0 & 0 & 0.0 & 50 & 100.0 \\
\hline $\begin{array}{l}\text { 10.Prepare a sterile surgical equipment for changing the dressing of the patient } \\
\text { with burns }\end{array}$ & 0 & 0.0 & 4 & 8.0 & 46 & 92.0 \\
\hline $\begin{array}{l}\text { 11.Used disinfection to sterilize the bathroom washing between patient and } \\
\text { another }\end{array}$ & 8 & 16.0 & 23 & 46.0 & 19 & 38.0 \\
\hline 12.Check the temperature of water used to wash the burns' & 14 & 28.0 & 26 & 52.0 & 10 & 20.0 \\
\hline 13.Used a sterile medical solution (iodine) to sterilize the affected burns area & 0 & 0.0 & 0 & 0.0 & 50 & 100.0 \\
\hline 14.Wearing a head cover & 46 & 92.0 & 2 & 4.0 & 2 & 4.0 \\
\hline 15.Used ointments for dressing burn wound & 0 & 0.0 & 0 & 0.0 & 50 & 100.0 \\
\hline 16.Wearing a sterile uniform & 1 & 2.0 & 5 & 10.0 & 44 & 88.0 \\
\hline 17.Wearing a respiratory face mask & 1 & 2.0 & 5 & 10.0 & 44 & 88.0 \\
\hline 18.Wearing a sterile gloves for each patient & 0 & 0.0 & 0 & 0.0 & 50 & 100.0 \\
\hline 19.Wearing a special shoes (slipper) for burn units & 47 & 94.0 & 0 & 0.0 & 3 & 6.0 \\
\hline $\begin{array}{l}\text { 20.Prepare a sterile dressing materials such as cotton -to wrap medical gauze and } \\
\text { bandages }\end{array}$ & 0 & 0.0 & 0 & 0.0 & 50 & 100.0 \\
\hline 21.Wash the affected body burns daily and remove dead tissues & 0 & 0.0 & 21 & 42.0 & 29 & 58.0 \\
\hline 22.Check the discharge from burn area & 0 & 0.0 & 4 & 8.0 & 46 & 92.0 \\
\hline 23.Cheek the healing of burn area & 0 & 0.0 & 3 & 6.0 & 47 & 94.0 \\
\hline $\begin{array}{l}\text { 24. Elevate the affected child limbs to decrease of burn edema (swelling) as a } \\
\text { result of burns injury }\end{array}$ & 0 & 0.0 & 15 & 30.0 & 35 & 70.0 \\
\hline 25.Select appropriate cannula of right size & 0 & 0.0 & 2 & 4.0 & 48 & 96.0 \\
\hline 26.Choose a place free from burns to put of the cannula & 0 & 0.0 & 1 & 2.0 & 49 & 98.0 \\
\hline $\begin{array}{l}\text { 27.Checking insertion site of cannula set (hematoma, swelling,bleeding) and } \\
\text { intravenous infusion }\end{array}$ & 0 & 0.0 & 1 & 2.0 & 49 & 98.0 \\
\hline $\begin{array}{l}\text { 28.Calculate the amount of fluid by weight and severity of burn and the degree of } \\
\text { burn }\end{array}$ & 0 & 0.0 & 10 & 20.0 & 40 & 80.0 \\
\hline 29. Observe signs of the inflammation localized to the site of the cannula & 0 & 0.0 & 8 & 16.0 & 42 & 84.0 \\
\hline 30.The presence of fluid calculation sheet in the child chart & 1 & 2.0 & 3 & 6.0 & 46 & 92.0 \\
\hline 31.Monitor the $\mathrm{O} 2$ concentration and of infiltration supply & 13 & 26.0 & 35 & 70.0 & 2 & 4.0 \\
\hline $\begin{array}{l}\text { 32. Observe breathing and child response to } \mathrm{O} 2 \text { therapy includes (rapid breathing } \\
\text { cyanosis and tachycardia) of child }\end{array}$ & 5 & 10.0 & 44 & 88.0 & 1 & 2.0 \\
\hline 33.Use the stethoscope to check for the amount of air entering to the child's lungs & 48 & 96.0 & 1 & 2.0 & 1 & 2.0 \\
\hline $\begin{array}{l}\text { 34.Document the rate of } \mathrm{O} 2 \text { and the concentration and the time given } \mathrm{O} 2 \text { in the } \\
\text { child chart }\end{array}$ & 9 & 18.0 & 36 & 72.0 & 5 & 10.0 \\
\hline 35.Daily weight of the child & 1 & 2.0 & 0 & 0.0 & 49 & 98.0 \\
\hline 36.Continuous movement of affected Joint(exercise) & 0 & 0.0 & 19 & 38.0 & 31 & 62.0 \\
\hline 37.Used the (support splint) for affected limbs & & & 10 & 20.0 & 40 & 80.0 \\
\hline 38.Change the child position every two hours & 0 & 0.0 & 37 & 74.0 & 13 & 26.0 \\
\hline 39.Prepare the necessary equipment follies catheter procedure & 0 & 0.0 & 0 & 0.0 & 50 & 100.0 \\
\hline 40.Used disinfection solution for cleaning of genital area at procedure & 0 & 0.0 & 3 & 6.0 & 47 & 94.0 \\
\hline 41.Selected appropriate size of catheter at procedure & 0 & 0.0 & 0 & 0.0 & 50 & 100.0 \\
\hline 42.Observe signs of the localized inflammation at site of urinary catheter & 2 & 4.0 & 12 & 24.0 & 36 & 72.0 \\
\hline 43.Give the treatment as recorded in the child's chart & 0 & 0.0 & 0 & 0.0 & 50 & 100.0 \\
\hline 44.Send the blood samples to the laboratory for potassium and calcium checking & 1 & 2.0 & 2 & 4.0 & 47 & 94.0 \\
\hline 45.Follow-up results of the tests & 0 & 0.0 & 27 & 54.0 & 23 & 46.0 \\
\hline 46.Put results of the tests in the child's chart & 0 & 0.0 & 0 & 0.0 & 50 & 100.0 \\
\hline
\end{tabular}




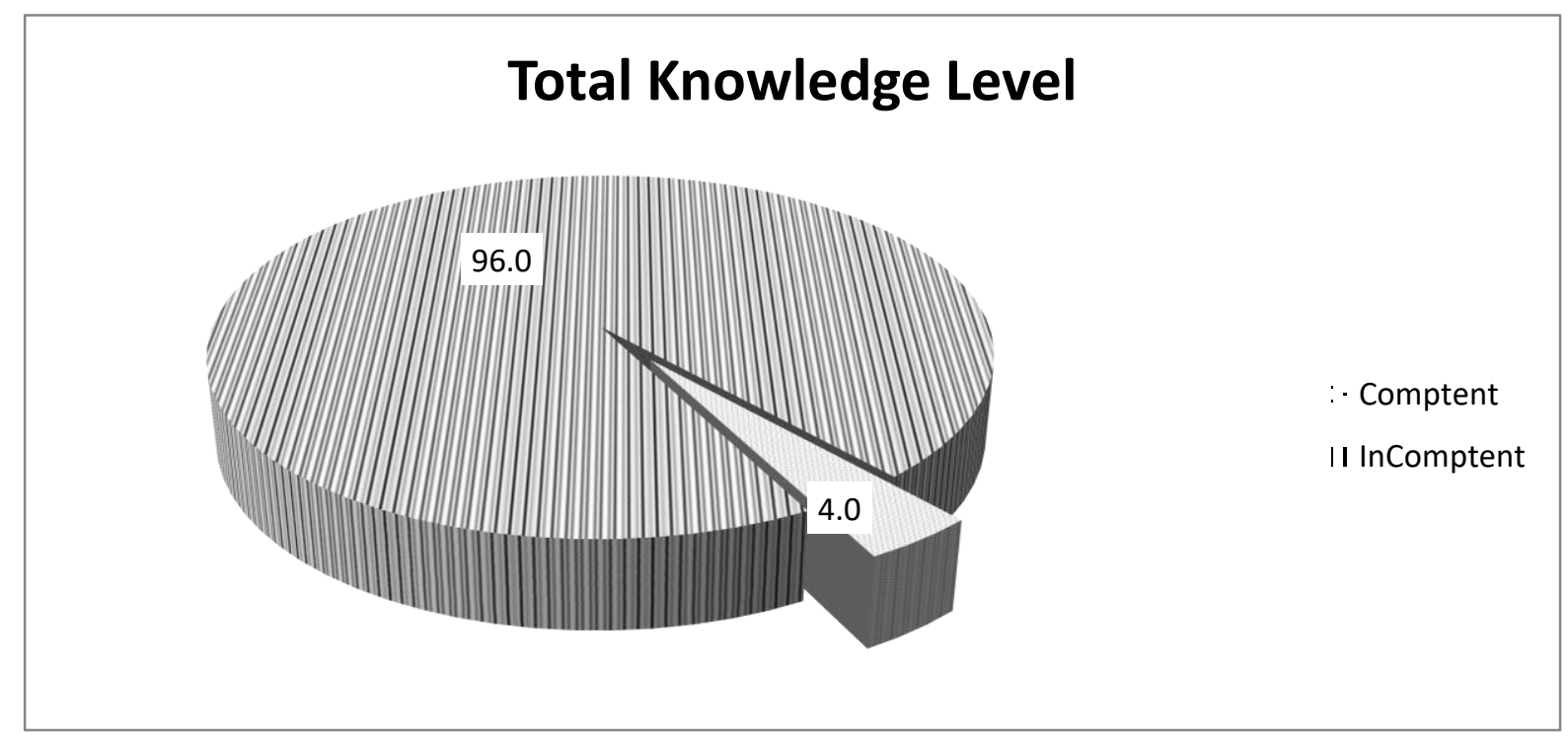

Figure (1): Total knowledge score of studied nurses

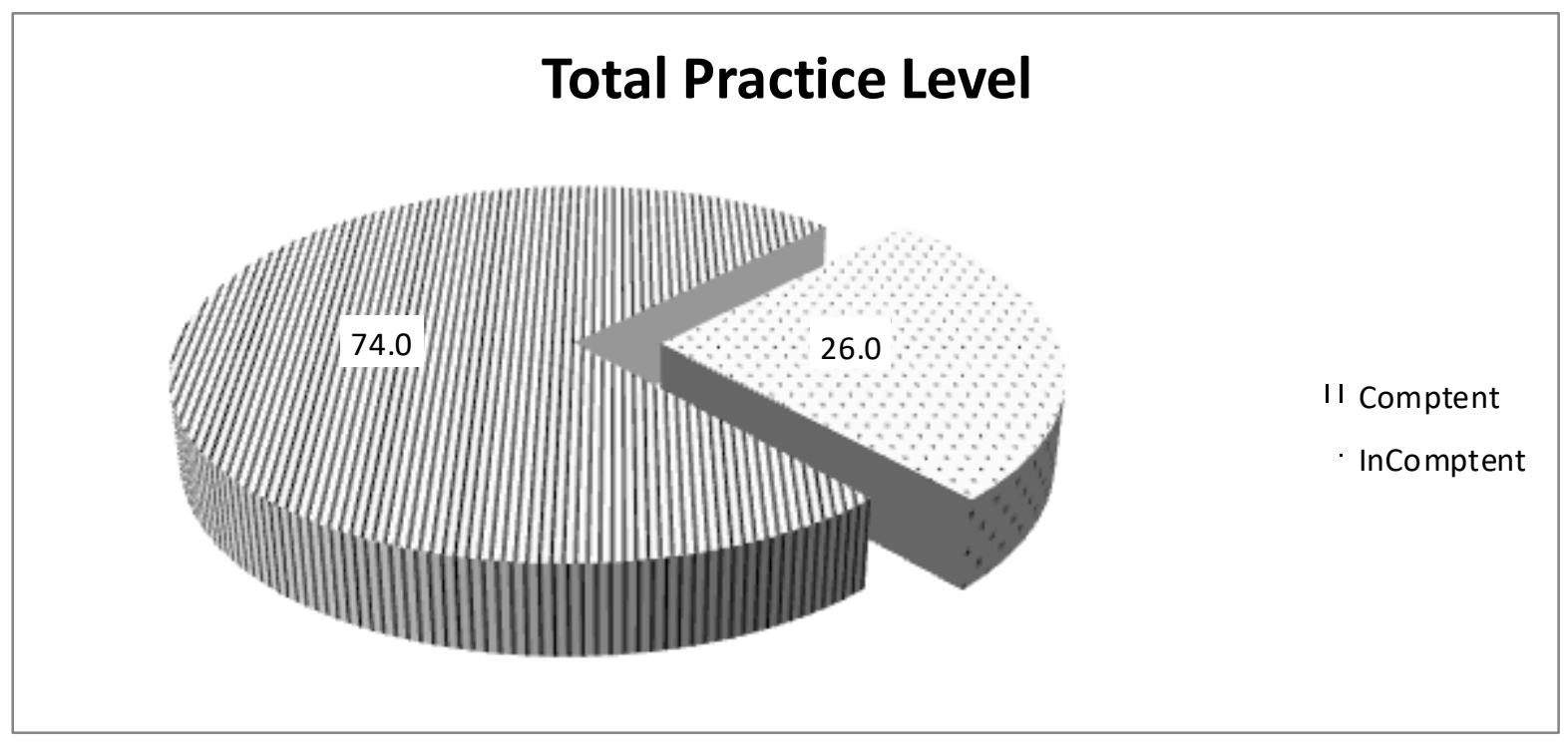

Figure (2): Total practice score of studied nurses. 
Table (4):- Relationship between Nurses' Knowledge level with their Characteristics of studied nurses (n=50)

\begin{tabular}{|c|c|c|c|c|c|c|}
\hline \multirow{3}{*}{ Characteristics } & & \multicolumn{5}{|c|}{ Nursing Knowledge Level } \\
\hline & \multicolumn{2}{|c|}{ Incompetent $(n=48)$} & \multicolumn{2}{|c|}{ Competent(n=2) } & \multirow[t]{2}{*}{$\mathbf{X}^{2}$} & \multirow{2}{*}{ P. value } \\
\hline & No & $\%$ & No & $\%$ & & \\
\hline \multicolumn{7}{|l|}{ Age group/ years } \\
\hline From 20 - years & 24 & 50.0 & 0 & 0.0 & \multirow{3}{*}{3.125} & \multirow{3}{*}{0.210} \\
\hline From 25 - years & 6 & 12.5 & 0 & 0.0 & & \\
\hline More than 30 years & 18 & 37.5 & 2 & 100.0 & & \\
\hline \multicolumn{7}{|l|}{ Marital Status } \\
\hline Single & 22 & 45.8 & 0 & 0.0 & \multirow{3}{*}{0.177} & \multirow{3}{*}{0.412} \\
\hline Married & 25 & 52.1 & 2 & 100.0 & & \\
\hline Widowed & 1 & 2.1 & 0 & 0.0 & & \\
\hline \multicolumn{7}{|l|}{ Educational Level } \\
\hline Nursing Diploma & 15 & 31.3 & 2 & 100.0 & & \multirow{5}{*}{0.400} \\
\hline $\begin{array}{l}\text { Diploma of Nursing }+ \\
\text { Specialty }\end{array}$ & 3 & 6.3 & 0 & 0.0 & \multirow{4}{*}{4.044} & \\
\hline $\begin{array}{ll}\text { Nursing } & \text { Technician } \\
\text { Institute } & \\
\end{array}$ & 15 & 31.3 & 0 & 0.0 & & \\
\hline Bachelor of Nursing & 4 & 8.3 & 0 & 0.0 & & \\
\hline $\begin{array}{l}\text { Healthy } \\
\text { Institute }\end{array}$ & 11 & 22.9 & 0 & 0.0 & & \\
\hline \multicolumn{7}{|l|}{ Years of experience } \\
\hline$>1-$ year & 11 & 22.9 & 0 & 0.0 & \multirow{4}{*}{5.667} & \multirow{4}{*}{0.129} \\
\hline From 1- years & 14 & 29.2 & 0 & 0.0 & & \\
\hline From 5 - years & 3 & 6.3 & 1 & 50.0 & & \\
\hline More than 10 & 20 & 41.7 & 1 & 50.0 & & \\
\hline \multicolumn{7}{|l|}{ Training Courses } \\
\hline Yes & 44 & 91.7 & 2 & 100.0 & \multirow{2}{*}{0.818} & \multirow{2}{*}{0.670} \\
\hline No & 4 & 8.3 & 0 & 0.0 & & \\
\hline \multicolumn{7}{|l|}{ Courses Number } \\
\hline Less than 3 courses & 33 & 73.3 & 2 & 100.0 & \multirow{2}{*}{0.001} & \multirow{2}{*}{0.970} \\
\hline More than 3 courses & 11 & 25.0 & 0 & 0.0 & & \\
\hline
\end{tabular}

-Chi-square test

Table (5): Relationship between Nursing Practice Level with their Characteristics of studied nurses (n=50).

\begin{tabular}{|c|c|c|c|c|c|c|}
\hline \multirow{3}{*}{ Characteristics } & & \multicolumn{5}{|c|}{ Nursing Practice Level } \\
\hline & \multicolumn{2}{|c|}{ incompetent(n=13) } & \multicolumn{2}{|c|}{ competent $(n=37)$} & \multirow{2}{*}{$\mathbf{X}^{2}$} & \multirow[t]{2}{*}{ P. value } \\
\hline & No & $\%$ & No & $\%$ & & \\
\hline \multicolumn{7}{|l|}{ Age group /years } \\
\hline From 20 - years & 10 & 76.92 & 14 & 37.84 & \multirow{3}{*}{6.428} & \multirow{3}{*}{$0.040 *$} \\
\hline From 25 - years & 0 & 0.00 & 6 & 16.22 & & \\
\hline More than 30 years & 3 & 23.08 & 17 & 45.95 & & \\
\hline \multicolumn{7}{|l|}{ Marital Status } \\
\hline Single & 7 & 53.85 & 15 & 40.54 & \multirow{3}{*}{0.939} & \multirow{3}{*}{0.625} \\
\hline Married & 6 & 46.15 & 21 & 56.76 & & \\
\hline Widowed & 0 & 0.00 & 1 & 2.70 & & \\
\hline \multicolumn{7}{|l|}{ Educational Level } \\
\hline Nursing Diploma & 2 & 15.38 & 15 & 40.54 & \multirow{3}{*}{9.021} & \multirow{3}{*}{0.061} \\
\hline Diploma of Nursing + Specialty & 0 & 0.00 & 3 & 8.11 & & \\
\hline Nursing Technician Institute & 8 & 61.54 & 7 & 18.92 & & \\
\hline
\end{tabular}




\begin{tabular}{|c|c|c|c|c|c|c|}
\hline \multirow{3}{*}{ Characteristics } & & \multicolumn{5}{|c|}{ Nursing Practice Level } \\
\hline & \multicolumn{2}{|c|}{ incompetent(n=13) } & \multicolumn{2}{|c|}{ competent $(n=37)$} & \multirow{4}{*}{$X^{2}$} & \multirow[t]{2}{*}{ P. value } \\
\hline & No & $\%$ & No & $\%$ & & \\
\hline Bachelor of Nursing & 1 & 7.69 & 3 & 8.11 & & \\
\hline Healthy Technician Institute & 2 & 15.38 & 9 & 24.32 & & \\
\hline \multicolumn{7}{|l|}{ Years of experience } \\
\hline$>1$ year & 6 & 46.15 & 5 & 13.51 & \multirow{4}{*}{7.672} & \multirow{4}{*}{0.053} \\
\hline From 1- years & 4 & 30.77 & 10 & 27.03 & & \\
\hline From 5 -years & 1 & 7.69 & 3 & 8.11 & & \\
\hline More than 10 & 2 & 15.38 & 19 & 51.35 & & \\
\hline \multicolumn{7}{|l|}{ Training Courses } \\
\hline Yes & 11 & 84.62 & 35 & 94.59 & \multirow{2}{*}{0.299} & \multirow{2}{*}{0.254} \\
\hline $\mathrm{No}$ & 2 & 15.38 & 2 & 5.41 & & \\
\hline \multicolumn{7}{|l|}{ Courses Number } \\
\hline Less than 3 courses & 9 & 81.82 & 26 & 74.28 & \multirow{2}{*}{0.011} & \multirow{2}{*}{0.523} \\
\hline More than 3 courses & 2 & 18.18 & 9 & 25.7 & & \\
\hline
\end{tabular}

- Chi-square test, $*$ Significant difference at $p$. value $<0.05$

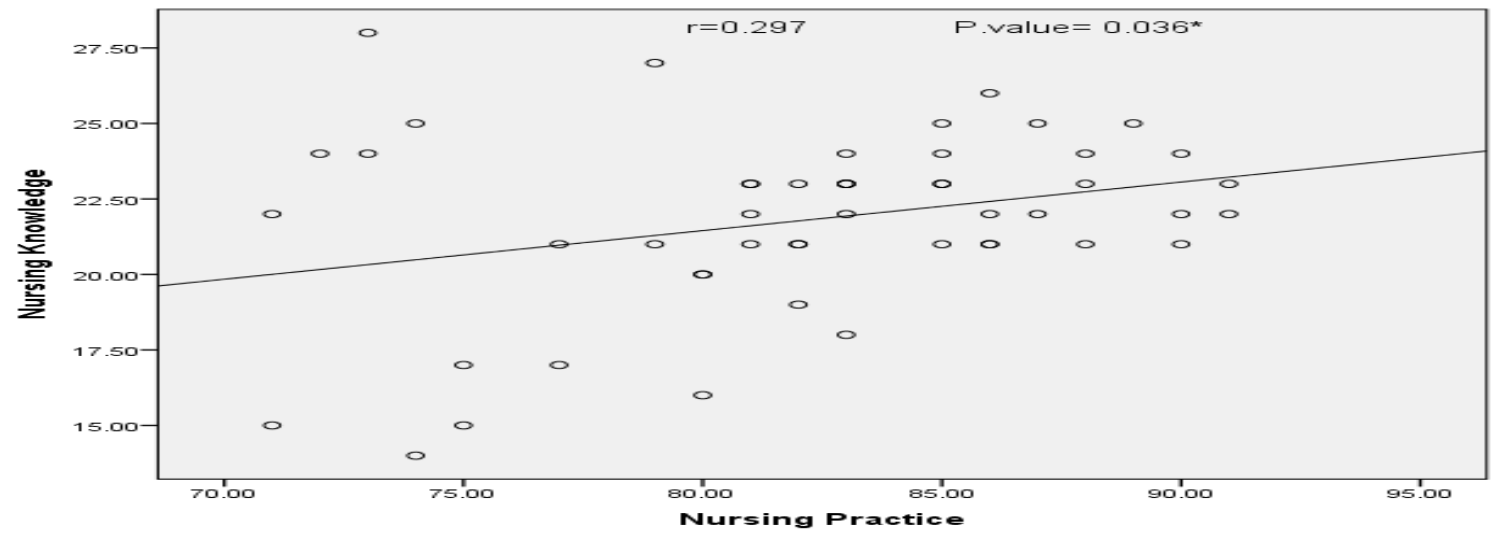

Figure (3): Co-relation co-efficient between total score of the studied nurses' level of knowledge and practice regarding care of pediatric burns.

Table (1): Demonstrates characteristics of studied nurses. It was observed that near to half of studied nurses $(48 \%)$ aged from $20-25$ years and more than half of them $(54 \%)$ were married. It was found that more than one third of nurses had diploma degree in nursing (34\%). It was found that more than two fifths of studied nurses (42\%) had experience from 10 and more years. It was observed that the majority of the studied nurses (92\%) attend training courses about nursing care for burn patients (60\%).

Table (2): Demonstrates knowledge of studied sample regarding burn it was observed that all nurses have complete correct knowledge about nursing care of pediatric burn patient (100\%). The majority of nurses have incomplete correct knowledge about complications of burn (98\%). As regard medication for pediatric burn patient more than one third of nurses didn't have knowledge about it (34\%).

Table (3): Demonstrates practice of studied sample regarding burn. It notes all nurses' (100\%) done complete correct in items regarding practice about care of burn child include right name of physician, preparation of the child's bed, used a sterile medical solution (iodine) to sterilize the affected burns area, used ointments for dressing burn wound, wearing a sterile gloves for each patient, prepare a sterile dressing materials such as cotton -to wrap medical gauze and bandages, prepare the necessary equipment follies catheter procedure, selected appropriate size of catheter at procedure, give the treatment as recorded in the child's chart and put results of the tests in the child's chart. The majority of nurses were 
not done the item as ask about child's past and present medical history (80\%), wearing a head cover (92\%), Wearing a special shoes (slipper) for burn units (94\%) and Use the stethoscope to check for the amount of air entering to the child's lungs (96\%).

Table (4): Shows relationship between nurses' knowledge level with their Characteristics of studied nurses. It revealed that there is no statistical significant difference between age group, years of experience, educational level, marital status, training courses, courses number and level of knowledge.

Table (5): Shows relationship between nurses' practice level with their Characteristics of studied nurses. There is statistical significant difference between age group and level of practice. The old nurses had practice better than the young.

Figure (1): Indicates total knowledge score of studied nurses. It was found that lowest percentage $(4.0 \%)$ of the studied nurses had competent level of knowledge regarding burn and its management, while majority of them $(96.0 \%)$ had incompetent level and with mean \pm SD 21.80 \pm 2.98 .

Figure (2): Illustrates the total practice score of studied nurses. It was found that close to two-thirds (74\%) of them had competent level of performance and more than a quarter $(26.0 \%)$ of them had incompetent level with mean \pm SD 82.16 \pm 5.51 .

Figure (3): Demonstrates that, there was statistically significant positive Co-relation between total score of the studied nurses ' level of knowledge and practice $(\mathrm{p}$. value $=0.036)$.

\section{Discussion}

Burn injury is a significant problem in low and middle-income countries. Moreover, across regions children are more affected by burn injury than adults. Pediatric burn patients are at risk of many complications if immediate optimal nursing care is not provided, the outcome of burn injury is greatly influenced by the quality of care patients received. This care includes meeting nutritional needs, availability of resources such as dressing supplies, and skills among health care providers (Nyakanda, et al., 2019).

Marquis \& Huston, (2009) stated that education and training are two components of staff development that occur after an employees' indoctrination (which refers to planned, guided adjustment of employee to the organization and work environment). The staffs' knowledge level and capabilities are a major factor in determining the number of staff required to carry out unit goals. The better trained and more competence the staff, the fewer staff required, which in turn saves the organization money and rise reproductivity.
According to knowledge about care of pediatric burns. The present study noticed that lowest percentage $(4.0 \%)$ of the studied nurses had competent level of knowledge regarding burn and its management. while majority of them $(96.0 \%)$ had incompetent level of knowledge. This poor knowledge noticed among nurses' might be attributed to, after graduation, nurses abandon reading and neglect to update their professional knowledge. Another possible reason might be the absence of any resources or programs for continued nursing education. These results indicated that nurses' in burn unit should be exposed to raising awareness' programs. The same finding was reached by Abd EL-lateef (2011) who "conducted an educational program for prevention of infection in burn unit at Zagazig University" and reported that, total percent of nurses' knowledge was poor. This finding disagree with Mussa \& Abass, (2014) who carried out study about assessment of Nurses' Knowledge regarding nursing care for patients with burn and revealed that the nurses' knowledge of burn and nursing care were moderately adequate at Azady hospital compared to adequate knowledge at western hospital. Treatment showed adequate knowledge at both hospitals and complications of burn were moderately adequate at both hospitals.

Regarding nurses' practice about care of pediatric burns. The current study revealed that close to twothirds $(74 \%)$ of them had competent level of practice. This reflects that nurses neglect updating their professional knowledge and nurses performance of care burn child based on routine rather than research or current recommendation. this finding disagree with Ibrahim, et al., (2018) who reported that the majority of studied nurses had incompetent practice regarding care of burned children. Also, with Chan, et al., (2012) who found more than half of studied nurses had unsatisfactory practice regarding care of burned children.

The present study viewed that, there was no statistical significance relation between nurses' level of knowledge and characteristics data, this finding was supported by El-Sayed, et al., (2015) who found that there was no statistically significant relation between nurses' knowledge and characteristics data, this finding disagree with Ahmed \& Mohamed, (2011) who reported that there was statistical significant relation between nurses' knowledge and characteristics data.

The current study illustrated that, there were statistically significant relation between nurses' level of practice and age group $(\mathrm{P}<0.04)$. Nurses' age might be a factor as it plays a vital role in improving the nurses' practice. The present study found that the 
majority of the nurses with older age $>30$ years had satisfactory level of practice. This may be because older nurses had more years of experience for practical work in direct patient care. This finding in the same line with Ahmed. (2016) who found that, there was statistical significant difference between nurses' total performance scores and their age group. Regarding to relationship between nurses' level of practice and year of experiences, the current study showed that, there was no statistical significant relation between nurses' level of practice and years of experience. This may be because older nurses depend on younger nurses in work and they prefer to play administrative role only. These finding go on the same line with Abou Ahmed., (2013) who found that there was no relation between nurses' performance and years of experiences. This finding dissimilar with Ahmed, (2016) who found that, there was statistical significant relation between total nurses' performance and years of experience.

There was statistically significance positive correlation between total score of the studied nurses ' level of knowledge and practice .This finding was in the same line with Zaton (2013) \& Ismail (2010) who found that positive statistical correlation between total nurse' knowledge score and practice score. On the other hand, this finding disagree with Abd El- Aziz (2013) who mentioned that no statistical significant correlation between total nurses' knowledge score and practice score.

\section{Conclusion}

Based on the results of the present study, it can be concluded that: The majority of nurses' had incompetent level of knowledge. However, they are competent level of practice. There were statistically significant relation between total score of the studied nurses' level of knowledge and practice regarding care of pediatric burns.

\section{Recommendations}

Based on the results of the present study the following recommendations can be suggested

1. On job Training (OJT) programs on regular basis is suggested in order to refresh and update nurses' knowledge, as well as reinforce proper practice related to care given to child with burn.

2. Pediatric nurses should update their knowledge through continued nursing education, and frequently attending seminars and conferences based on their needs assessment.

3. Nursing program should focus on the basic principles and practices for infection control and patient - safety standards.
4. Nurses' attendance of films and audiovisual conferences about practical procedures to increase their awareness with the recent approaches.

5. Provide procedure manual handbook containing all essential information about nursing procedures.

6- Nurses' need more nursing research in pediatric burned for an effective and efficient burn care.

\section{References}

1. Abd El Aziz, E., (2013): Assessment of Nurses knowledge and practice related to Nosocomial Infection Control Measures at Intensive Care Unit. Zagazig University Hospitals. Unpublished Master Thesis, Faculty of Nursing, Zagazig University.

2. Abd El-lateef, A., (2011): Designing, implementation and evaluation an educational program for prevention of infection in burn unit. Unpublished doctoral thesis. Faculty of nursing, Zagazig University

3. Abou- Ahmed, (2013): compliance of nurses with neonatal care protocol regarding feeding in neonates, (master degree) Egypt, Faculty on nursing, Ain Shams University, Pp: 59-66.

4. Ahmed G., Sobhi M., \& Mohamed Z., (2011): Effect of designed nursing protocol on nurses Knowledge and Practice regarding hemodialysis patients at Assiut Children University Hospital. Unpublished Master Thesis in Pediatric Nursing, Faculty of Nursing, University of Assiut.

5. Ahmed H., (2016): Evaluation of Nursing performance at pediatric Burn Unit. IOSR Journal of Nursing and Health Science, Vol.5, PP.50-57.

6. Ahmed, H., \& Mohammed, A., (2016): Evaluation of nursing performance at Pediatric Burn Unit in Benha City: an intervention study. IOSR Journal of Nursing and Health Science (IOSR-JNHS), 5(6), 50-57.

7. Ahuja, R., Gibran, N., Greenhalgh, D., Jeng, J., Mackie, D., Moghazy, A., \& Watson, S., (2016): ISBI practice guidelines for burn care. Burns, 5ed, p.p953-1021.

8. American Burn Association (2015): The Management of Burn Trauma in Children and Teens.

9. Benjamin, D., \& Jaco, M., (2018): Burn nursing. In Total burn care (pp. 355-363). Elsevier.

10. Center for Research Injury \& Policy, CRIP. (2010): Burns fact sheet.

11. Chan, Q., Barzi, F., Cheney, L., Harvey, J., \&Holland, A., (2012): Burn size estimation in children: still a problem .Emergency Medicine Australasia, 24 (2):181-186. 
12. Edwards, S., \& Coyne, I., (2019): A Survival Guide to Children's Nursing-Updated Edition EBook. Elsevier Health Sciences

13. El-Sayed, Z, Gomaa, A., \& Abdel-Aziz, M., (2015): Nurses' Knowledge and Performance for Prevention of Infection in Burn Unit at a University Hospital: Suggested Nursing Guidelines, Journal of Nursing and Health Science Volume 4, Issue 4 Ver. I PP 6269.www.iosrjournals.org

14. Gonzalez, R., \& Shanti, C., (2015, February): Overview of current pediatric burn care. In Seminars in pediatric surgery (Vol. 24, No. 1, pp. 47-49). WB Saunders

15. Henneman, E., Gawlinski, A., \& Giuliano, K., (2012): Surveillance: a strategy for improving patient safety in acute and critical care units. Critical Care Nurse, 32(2), p.p9-18.

16. Ibrahim, M., Abusaad, F., \& Elbilgahy, A., (2018): Current Nursing Practices for Managing Children with Burn Injuries. International journal of Nursing Didactics, 8(04), 01-06.

17. Ismail, B., (2010): Assessment of Nurses Awareness and Attitude toward Infection Control Concept at El- Mania University Hospital. Unpublished Master Thesis, Faculty of Nursing, Cairo University.

18. Marquis L., \& Huston J., (2009): Leader ship roles and management functions in nursing, 6th ed, chp9, Lippincott, HongKong, Pp.371-375

19. Mussa, M., \& Abass, S., (2014): Assessment of Nurses Knowledge Regarding Nursing Care for Patients with Burn. Journal of Natural Sciences ResearchVol.4, No.7. www.iiste.org

20. Nyakanda, P., \& Tarimo, E., (2019): Provision of care to hospitalized pediatric burn patients: a qualitative study among nurses at Muhimbili National Hospital, Dar es Salaam, Tanzania. BMC nursing, 18(1), 8.

21.Price, J., (2016):International Medical Work Experience. For Schools and University students. Gap Medics.

22. World Health Organization (2016): Burns. Fact sheet.

23. Zatton, H., (2013): Assessment of Knowledge and Practice among Nurses Caring for Patients with Hepatitis. Unpublished Master Thesis, Faculty of Nursing, Zagazig University. 